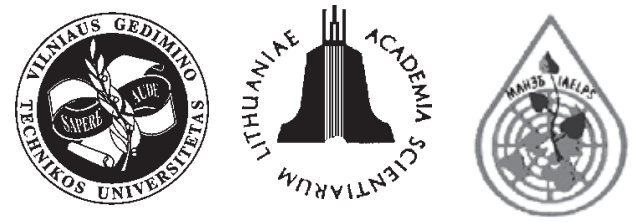

\title{
EXPERIMENTAL INVESTIGATION OF A FILTER WITH NATURAL SORBENT CHARGE FOR RUNOFF CLEANING FROM HEAVY METALS AND PETROLEUM PRODUCTS
}

\author{
Pranas Baltrẻnas, Evelina Brannvall \\ Dept of Environmental Protection, Vilnius Gediminas Technical University, Sauletekio al. 11, \\ LT-10223Vilnius-40,Lithuania.E-mail: eveli@st.vtu.lt
}

Submitted 22 Dec 2005; accepted 29 Dec 2005

\begin{abstract}
An experimental investigation on the removal of heavy metals (HM) and petroleum products (PP) from a solution by natural sorbents zeolite and vermiculite was carried out in a laboratory pilot-scaled test bench. For this purpose a model of a runoff filter which was invented by the authors was used. $25 \mathrm{~kg}$ of natural zeolite and $2 \mathrm{~kg}$ of vermiculite were used for the filter charge. An experimental solution of 201 contained $1 \mathrm{~g} / \mathrm{l}$ of $\mathrm{HM} \mathrm{Cu}, \mathrm{Pb}, \mathrm{Zn}, \mathrm{Ni}$ and Mn nitrates and $200 \mathrm{ml}$ of PP gasoline and diesel. The solution was poured into the filter through a funnel and passed over natural zeolite and vermiculite media. The first sample was taken through a sample mixer tap immediately after the contact of the experimental solution with the charge media, the second sample was taken after 5 min, then after 10 , 20, 30, 60, 120, 240, 360 and $720 \mathrm{~min}$. TOG/TPH analyser was used for measuring concentration of filtrate samples. The highest efficiency of $99,7 \%$ was reached for PP removal from water.
\end{abstract}

Keywords: petroleum products (PP), heavy metals (HM), water pollution, natural sorbent, zeolite, vermiculite.

\section{Introduction}

Runoff pollution is associated with rainwater or melting snow that washes off roads, bridges, parking lots, rooftops, and other impermeable surfaces. As it flows over these surfaces, water picks up dirt and dust, rubber and metal deposits from tire wear, antifreeze and engine oil that have dripped onto the road surface. Contaminants in runoff pollution from roads, highways, and bridges include: sediment, $\mathrm{HM}$ (V, Cr, Mn, Co, Ni, Cu, Zn, Cd and Pb) and pesticides, oils and grease $[1,2]$.

Methods for treating storm water usually involve retaining a large volume of water in a detention pond to allow pollutants to separate out before controlled release into a local watercourse. This helps to reduce the HM load associated with particulate matter, but is less efficient for metals in a dissolved phase of storm water [3]. The removal of soluble HM can be aided by clay lining in detention ponds and certain types of reeds in wetland systems [4-5].

There are a lot of different natural and artificial materials which could be applied for runoff treatment and in other fields. For example, fly ash is used for wastewater treatment and waste paper sludge ash - as a binder in the production of concrete [6-7].
An ion exchange material could provide additional storm water treatment by replacing any toxic HM cations in runoff with cations, such as sodium, calcium or magnesium. This technology could then reduce the HM level in motorway storm water through retention within an ion exchange material which could be re-generated for further use. Such methods would ideally be unaffected by the seasonally high salt contents of motorway storm water, due to the application of de-icing agents during winter. Zeolites are a suitable choice, as they have a large cation exchange capacity and an affinity for HM [8].

The aim of this study was to create a runoff-cleaning filter with a natural sorbent charge and calculate its efficiency. Natural zeolite employed was from a deposit near the village of Sokyrnytsia in the Ukrainian Transcarpathian region.

In recent years investigation of natural zeolite and vermiculite use for HM and PP removal from runoff was started in Lithuania [9-11]. Several researchers in their investigations tried to apply natural zeolite for storm water cleaning $[12,13]$. The authors presume that the best way of zeolite application for storm water treatment is to place it into a filter with an easy periodical regeneration of filter charges. Considering a practical aspect, a lager par- 
ticle size of material should be used (not less than $1 \mathrm{~mm}$ ). Since the best runoff treatment way is use of a filter with a natural sorbent charge, a runoff-cleaning filter was constructed [14].

\section{Methodology for testing efficiency of a runoff-clean- ing filter}

Runoff cleaning efficiency was tested using a pilot test bench - a model of a runoff filter.

A runoff-cleaning filter model differs from the designed system by used materials, frame and cassette shape, which is rectangular. The Perspex was used for the filter model, in order to see the composition of the charge. $25 \mathrm{~kg}$ of natural zeolite and $2 \mathrm{~kg}$ of vermiculite were used for the filter charge. A pilot test bench is shown in Fig 1.

An experimental solution of 201 contained $1 \mathrm{~g} / 1$ of $\mathrm{HM} \mathrm{Cu}, \mathrm{Pb}, \mathrm{Zn}, \mathrm{Ni}$ and $\mathrm{Mn}$ nitrates and $200 \mathrm{ml}$ of each PP - gasoline and diesel. The experimental solution was poured into the filter (1) through a funnel (2) and passed over the natural zeolite media of $1-3 \mathrm{~mm}$ particle size (3) and vermiculite media of 1-3 mm particle size (4). The first sample was taken through a sample mixer tap (5) immediately after the contact of the experimental solution with the charge media, the second sample was taken after $5 \mathrm{~min}$, then after 10, 20, 30, 60, 120, 240, 360 and $720 \mathrm{~min}$. Filtrate was poured back into the filter until it was sorbed totally by the filter charge media (after $720 \mathrm{~min}$ ).

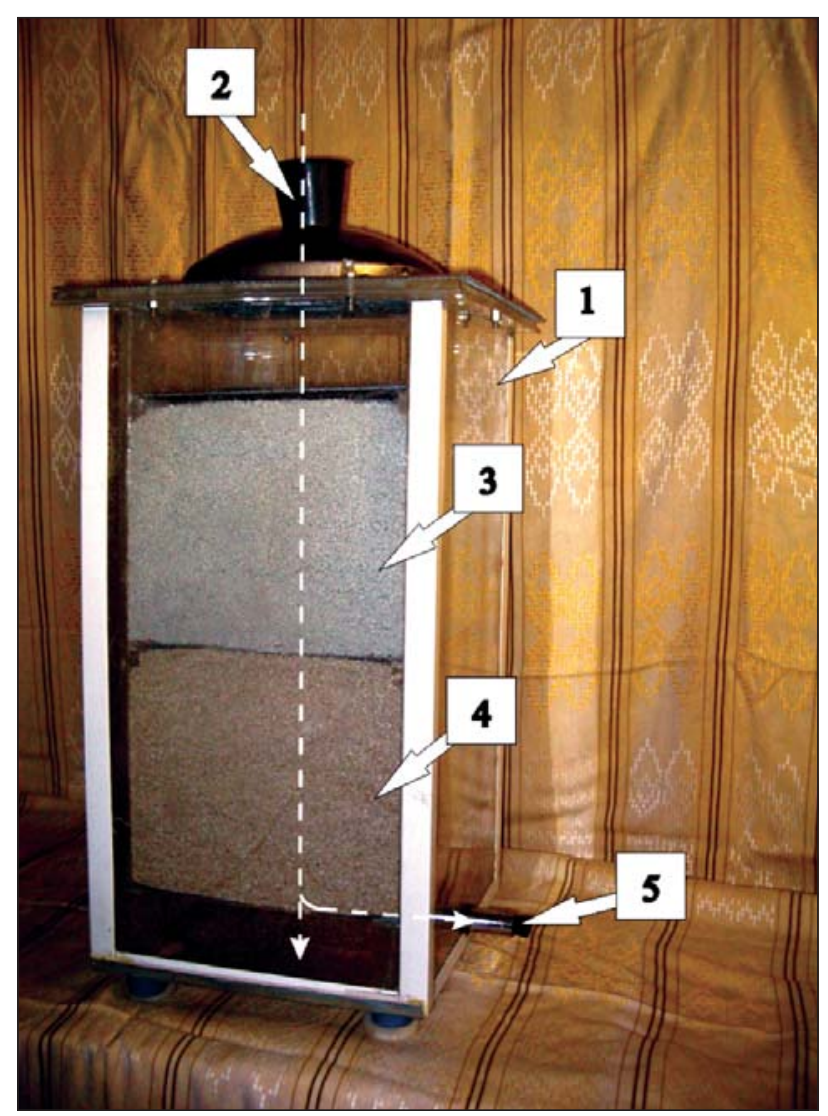

Fig 1. Runoff-cleaning filter model, a pilot test bench: 1 - filter, 2 - funnel, 3 - natural zeolite filter media, 4 - vermiculite filter media, 5 - sample mixer tap
Primary concentration of the experimental solution was measured as well. TOG/TPH analyser was used for the detection of PP concentrations in water and filtrate samples. The Model HATR-T Infracal TOG/TPH analyser is designed as an alternative for EPA Methods 413,2 and 418,1 that use Freon in the extraction procedure as well as for other applications where the concentration of a sample dissolved in an infrared transparent solvent is to be measured. Individual samples are prepared using the Hexane extraction procedure. To determine the contents using the Hexane extraction procedure and the Infracal TOG/TPH analyser, Model HATR-T, the sample is placed in the trough of the IR Platform. The Infracal IR Platform can provide quantitative information on oil and grease residue left on the reflecting surface after the hexane extractant has evaporated.

\section{Results}

In this study zeolite and vermiculite lowered the $\mathrm{pH}$ value from 7,9 of an experimental solution to 4,7 of the last filtrate sample after $720 \mathrm{~min}$ contact (Fig 2).

Primary concentration of $\mathrm{HM}(\mathrm{Pb}, \mathrm{Zn}, \mathrm{Cu}, \mathrm{Ni}$ and $\mathrm{Mn}$ ) in the experimental solution was $989,986,967,953$ and $993 \mathrm{mg} / \mathrm{l}$, respectively, and decreased by sorption of a natural sorbent charge (Figs 3-6). After 1 min of the experimental solution's contact with the filter media, $331 \mathrm{mg} /$ 1 of $\mathrm{Pb}, 659 \mathrm{mg} / \mathrm{l}$ of $\mathrm{Zn}, 680 \mathrm{mg} / \mathrm{l}$ of $\mathrm{Cu}, 640 \mathrm{mg} / \mathrm{l}$ of $\mathrm{Ni}$ and $808 \mathrm{mg} / \mathrm{l}$ of Mn remained in filtrate (Figs 3, 5). After $30 \mathrm{~min}$ of the experimental solution's contact with the filter media, $24 \mathrm{mg} / \mathrm{l}$ of Pb, $337 \mathrm{mg} / \mathrm{l}$ of $\mathrm{Zn}, 314 \mathrm{mg} / \mathrm{l}$ of Cu, $293 \mathrm{mg} / \mathrm{l}$ of $\mathrm{Ni}$ and $578 \mathrm{mg} / \mathrm{l}$ of $\mathrm{Mn}$ remained in filtrate.

After 720 min of the experimental solution's contact with the filter media, $14 \mathrm{mg} / \mathrm{l} \mathrm{of} \mathrm{Pb}, 179 \mathrm{mg} / \mathrm{l}$ of $\mathrm{Zn}, 131 \mathrm{mg} /$ 1 of $\mathrm{Cu}, 173 \mathrm{mg} / \mathrm{l}$ of $\mathrm{Ni}$ and $422 \mathrm{mg} / \mathrm{l}$ of $\mathrm{Mn}$ remained in filtrate (Figs 4, 6). Later the whole experimental solution was sorbed by the filter media.

Primary concentration of PP in the experimental solution was $308 \mathrm{mg} / \mathrm{l}$ (Fig 7). After $1 \mathrm{~min}$ of the experimental

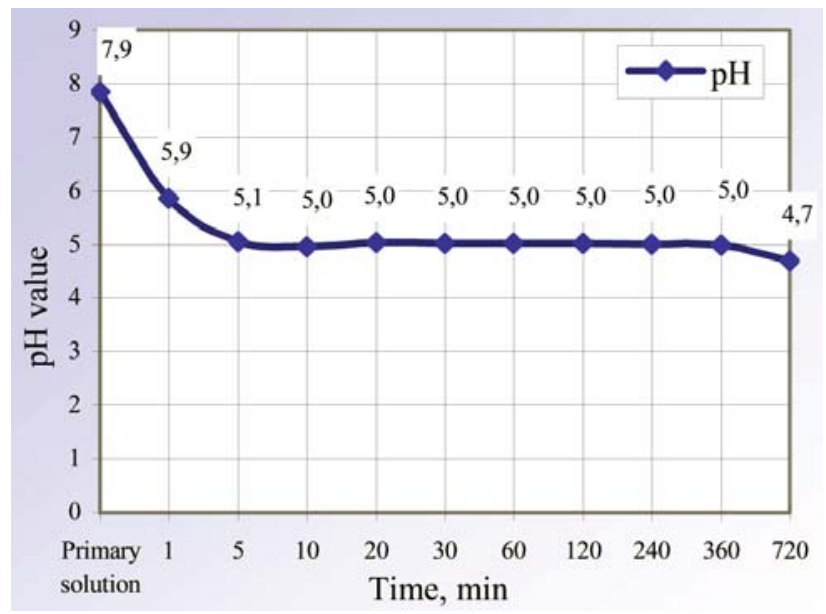

Fig 2. $\mathrm{pH}$ values of filtrate samples taken from runofffilter pilot test bench 
solution's contact with the filter media, $26 \mathrm{mg} / 1$ of PP remained in filtrate. After $30 \mathrm{~min}$, just $7 \mathrm{mg} / \mathrm{l}$ of PP remained in filtrate. After 720 min of the experimental solution's con-

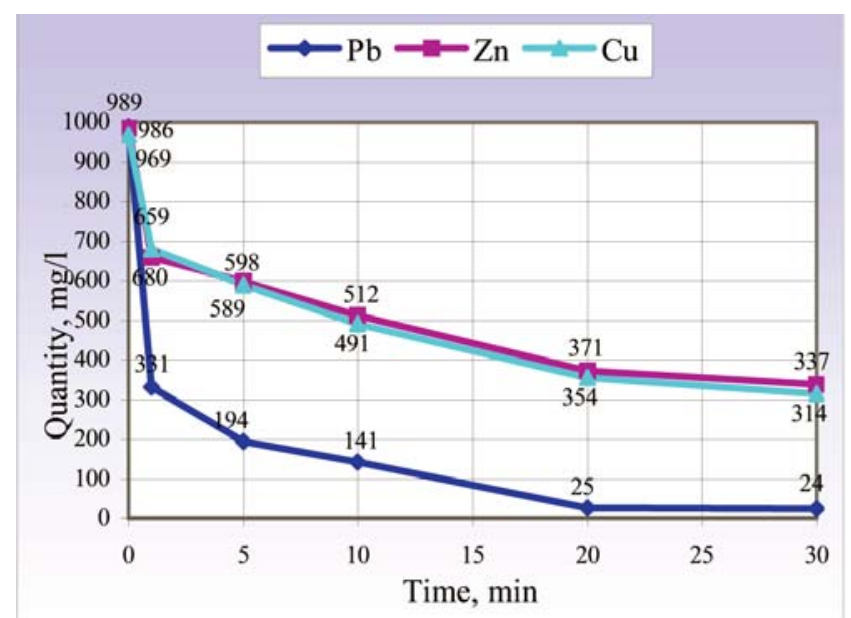

Fig 3. $\mathrm{Pb}, \mathrm{Cu}$ and $\mathrm{Zn}$ concentration in filtrate samples taken from runoff-filter pilot test bench during the first $30 \mathrm{~min}$

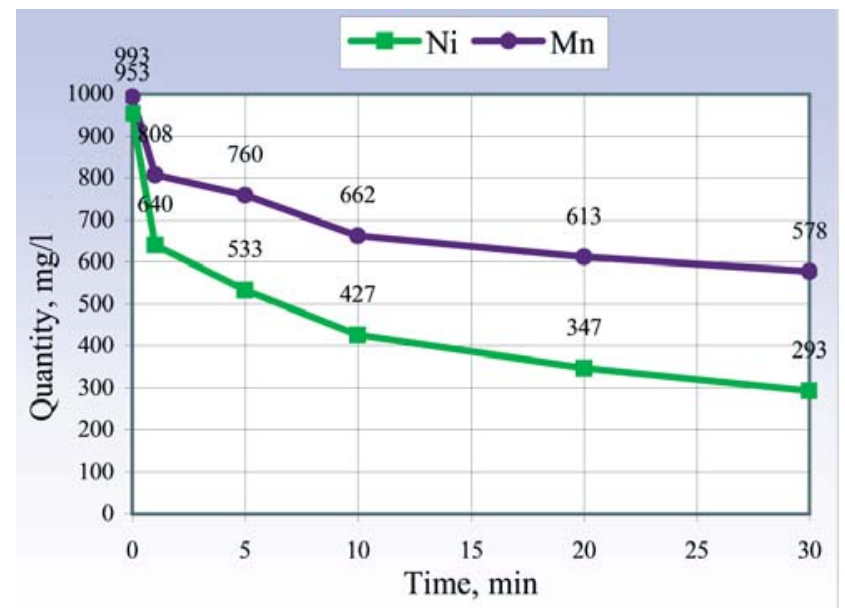

Fig 5. $\mathrm{Ni}$ and $\mathrm{Mn}$ concentration in filtrate samples taken from runoff-filter pilot test bench during the first $30 \mathrm{~min}$

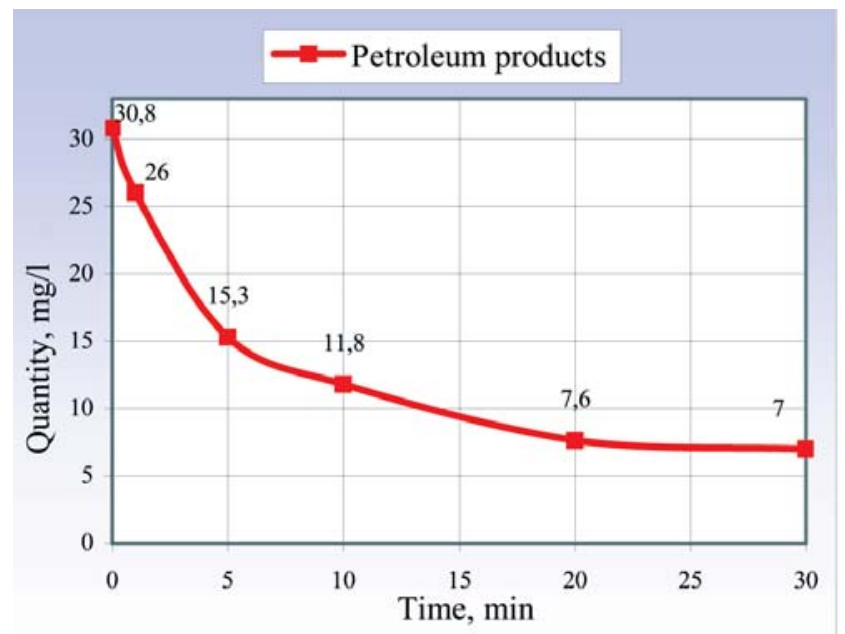

Fig 7. PP concentration in filtrate samples taken from runoff-filter pilot test bench during the first $30 \mathrm{~min}$ tact with the filter media, just $0,1 \mathrm{mg} / 1$ of PP remained (Fig 8).

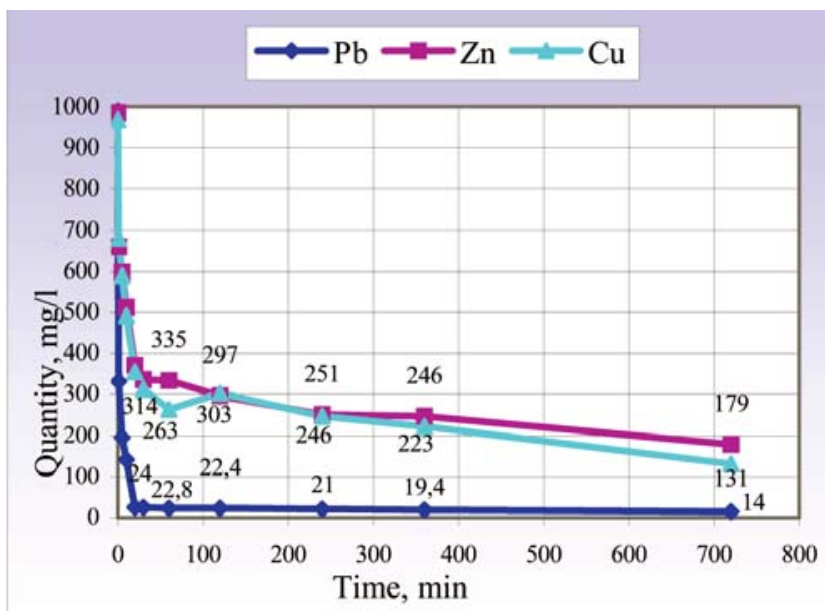

Fig 4. $\mathrm{Pb}, \mathrm{Cu}$ and $\mathrm{Zn}$ concentration in filtrate samples taken from runoff-filter pilot test bench

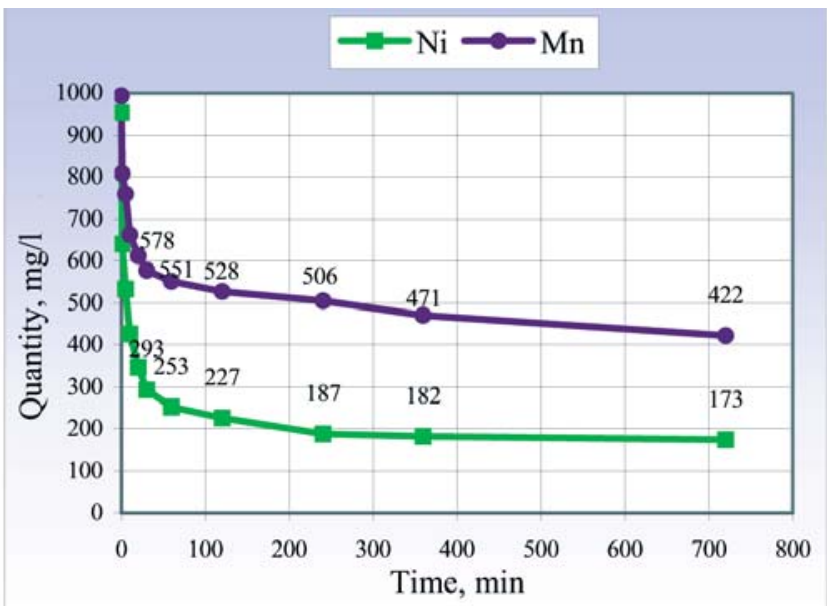

Fig 6. $\mathrm{Ni}$ and $\mathrm{Mn}$ concentration in filtrate samples taken from runoff-filter pilot test bench

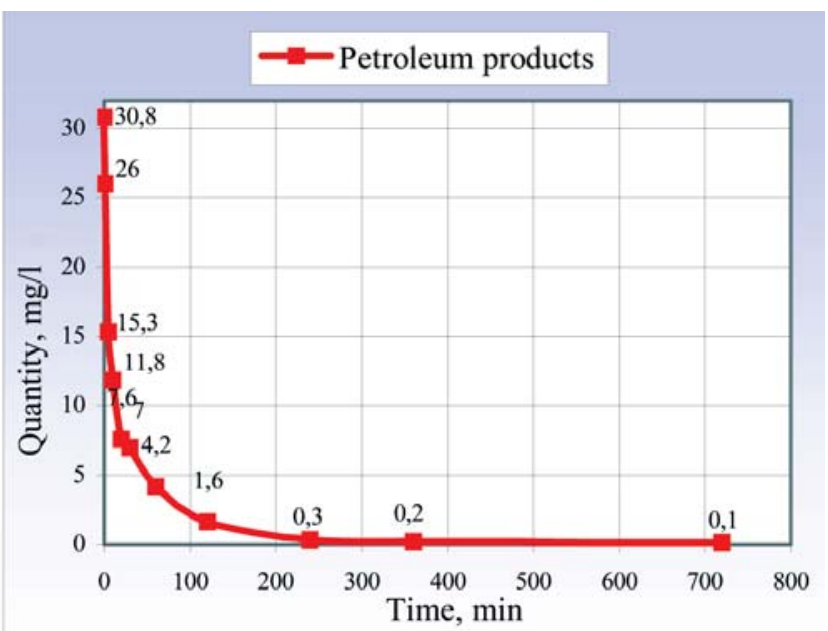

Fig 8. PP concentration in filtrate samples taken from runoff-filter pilot test bench 
Efficiency of runoff cleaning from HM and PP, \%

\begin{tabular}{|c|c|c|c|c|c|c|}
\hline $\begin{array}{c}\text { Time, } \\
\text { min }\end{array}$ & $\mathrm{Pb}$ & $\mathrm{Zn}$ & $\mathrm{Cu}$ & $\mathrm{Ni}$ & $\mathrm{Mn}$ & $\mathrm{PP}$ \\
\hline 1 & 66,5 & 33,2 & 29,8 & 32,8 & 18,6 & 15,6 \\
\hline 5 & 80,4 & 39,4 & 39,2 & 44,1 & 23,5 & 50,3 \\
\hline 10 & 85,7 & 48,1 & 49,3 & 55,2 & 33,3 & 61,7 \\
\hline 20 & 97,5 & 62,4 & 63,5 & 63,6 & 38,3 & 75,3 \\
\hline 30 & 97,6 & 65,8 & 67,6 & 69,3 & 41,8 & 77,3 \\
\hline 60 & 97,7 & 66,0 & 72,8 & 73,5 & 44,5 & 86,4 \\
\hline 120 & 97,7 & 69,9 & 68,7 & 76,2 & 46,8 & 94,8 \\
\hline 240 & 97,9 & 74,5 & 74,6 & 80,4 & 49,0 & 99 \\
\hline 360 & 98,0 & 75,1 & 77,0 & 80,9 & 52,6 & 99,4 \\
\hline 720 & 98,6 & 81,8 & 86,5 & 81,8 & 57,5 & 99,7 \\
\hline
\end{tabular}

After 1 min of the experiment HM and PP were sorbed by a natural zeolite and vermiculite from the experimental solution in the following order: $\mathrm{Pb}>\mathrm{Zn}>\mathrm{Ni}>\mathrm{Cu}>\mathrm{Mn}>\mathrm{PP}$.

But after a longer experimental solution's contact with the filter media the order of HM and PP sorption changed: $\mathrm{PP}>\mathrm{Pb}>\mathrm{Cu}>\mathrm{Zn}>\mathrm{Ni}>\mathrm{Mn}$. It could be explained by decrease of $\mathrm{pH}$ value in the solution which changed the sorption characteristics of natural sorbents.

The efficiency of HM and PP removal from the experimental solution was calculated by the formula:

$$
\text { Sorbed metal \% }=\left[\left(C_{r}-C_{m}\right) / C_{r}\right] \times 100,
$$

where $C_{r}$ - primary metal concentration in experimental solution, $C_{m}-$ metal concentration in experimental solution after contact with natural sorbent. in Table.

The results of runoff cleaning efficiency are shown

The efficiency of HM removal from water after 720 min of the experimental solution's contact with the filter charge media reached about $98,6 \%$ for $\mathrm{Pb}, 86,5 \%$ - for $\mathrm{Cu}, 81,8 \%$ - for $\mathrm{Zn}$ and $\mathrm{Ni}$ and 57,5 \% - for Mn. The highest efficiency of $99,7 \%$ was reached for PP removal from water. Even after $240 \mathrm{~min}$ the removal of PP from water was lower than MTP (Maximum Temporary Permissible) concentration in groundwater contaminated with $\mathrm{PP}$ in the territories of A and B categories, according to sensitivity to pollution [15].

\section{The runoff-cleaning filter}

The runoff-cleaning filter was designed and patented in the Lithuanian Republic Patent Bureau (Fig 9) [14].

This runoff-cleaning method could be employed in various branches of industry for treating wastewater and highway runoff-contaminated with metal ions and organic compounds (PP). The point of the proposed runoff-treatment filter is that pollutants are adsorbed and trapped in a natural mineral medium which is environmentally friendly, and pollutants don't migrate further.

The runoff-cleaning process using the runoff-cleaning filter is further shortly described. Highway runoff runs into a water-collecting well installed on a roadside. First of all water is cleaned from bigger branches, leaves, etc,

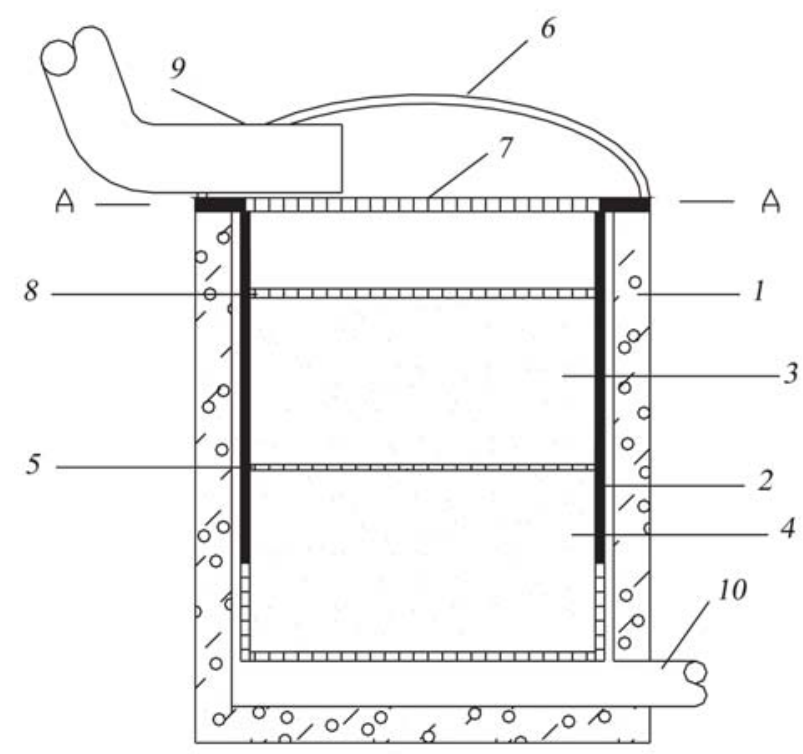

Fig 9. Runoff-cleaning filter scheme: 1 - ferroconcrete frame, 2 - removable cassette with fenestrated wall (1/4 part) and bottom, 3 - layer of natural zeolite adsorbent, 4 - layer of natural vermiculite adsorbent, 5 - metal grid of $<1 \mathrm{~mm}$ mesh diameter, 6 - cap, 7 - metal grid of 30-50 mm mesh diameter, $8-$ metal grid of $<2 \mathrm{~mm}$ mesh diameter, 9 - water inlet pipe, 10 - water outlet pipe

while passing through a grid with large gaps above the well. Then water runs through an inlet pipe into the filter and passes a grid with $30-50 \mathrm{~mm}$ mesh diameter (7). Then water is filtered through a cassette (2) with a natural sorbent charge $(3,4)$ installed in a ferroconcrete frame $(1)$ of the filter.

Natural zeolite (3) is hydrated aluminosilicate mineral of a porous structure with valuable physicochemical properties, such as cation exchange, molecular sieving, catalysis and sorption. Natural clinoptilolite employed in this study is a zeolite of the heulandite group that is the most abundant in nature. Natural zeolite of $1-3 \mathrm{~mm}$ particle size adsorbs $\mathrm{Pb}, \mathrm{Zn}, \mathrm{Cr}, \mathrm{Ni}, \mathrm{Mn}$, etc metal ions. Vermiculite (4) can be regarded as a micro-pore absorbent, if we consider the interpacked spaces of the crystal as pores. Vermiculite adsorbs PP [16-18]. Vermiculite of 1-3 mm particle size was used in the filter charge. Layers of sorbents are separated by a metal grid of $<1 \mathrm{~m}$ mesh diameter (5). Both charge layers are of the same volume which depends on the composition of runoff and the level of contamination with metal ions and organic compounds.

The runoff-cleaning filter cassette with a natural mineral sorbent charge is changed, depending on the intensity of highway exploitation and runoff contamination.

\section{Conclusions}

1. The highest efficiency of $99,7 \%$ was reached for PP removal from water after $720 \mathrm{~min}$ of an experimental solution's contact with the filter charge media. 
2. Even after $240 \mathrm{~min}$ the removal of PP from water is lower than MTP (Maximum Temporary Permissible) concentration in groundwater contaminated with PP.

3. After $720 \mathrm{~min}$ of the experimental solution's contact with the filter charge media, the efficiency of HM removal from water reached about $98,6 \%$ for $\mathrm{Pb}, 86,5 \%-$ for $\mathrm{Cu}, 81,8 \%$ - for $\mathrm{Zn}$ and $\mathrm{Ni}$ and 57,5 \% - for Mn.

4. The designed runoff-cleaning filter was suggested to install in the immediate vicinity of a road. Runoff directed by a chamfer into a water-collecting well and cleaned from big branches, leaves, etc, and then through the filter charge media. Water passing through the filter media is cleaned from metal ions (HM) and organic compounds (PP).

5. On the other hand, we suggest to install the runoff-cleaning filter after sedimentation ponds where the primary treatment of runoff is executed.

\section{References}

1. Sansalone, J. J.; Buchberger, S. G. Characterisation of solid and metal element distributions in urban highway stormwater. Water Science Technology, Vol 36 (8-9), 1997, p 155-160.

2. Davis, A. P.; Shokouhian, M.; Ni, S. Loading estimates of lead, copper, cadmium and zinc in urban runoff from specific sources. Chemosphere, Vol 44, 2001, p 997-1009.

3. Pontier, H.; May, E.; Williams, J. B. Constructed wetlands for the treatment of runoff from the Newbury bypass. Journal of CIWEM, Vol 15, 2001, p 125-129.

4. Hares, R. J.; Ward, N. I. Comparison of the heavy metal content of motorway stormwater following discharge into wet biofiltration and dry detention ponds along the London Orbital (M25) motorway. Science of the Total Environment, Vol 235, 1999, p 169-178.

5. Shutes, R. B. E.; Revitt, D. M.; Lagerberg, I. M.; Barraud, V. C. E. The design of vegetative constructed wetlands for the treatment of highway runoff. Science of the Total Environment, Vol 235, 1999, p 189-197.

6. Gailius, A.; Laurikietyte, Ž. Waste paper sludge ash and ground granulated blast-furnace slag used as binder in the production of concrete. Journal of Civil Engineering and Management, Vol IX, No 3. Vilnius: Technika, 2003, p 198202.

7. http://www.flyash.info/2005/4rey.pdf
8. Pitcher, S. K.; Slade, R. C. T.; Ward, N. I. Heavy metal removal from motorway stormwater using zeolites. Science of the Total Environment, Vol 334-335, 2004, p 161166.

9. Anisimova, R.; Brannvall, E.; Paliulis, D.; Jaskelevičius, B. Experimental investigation and analysis of using natural zeolite for heavy metal sorption from aquatic solutions. Journal of Environmental Engineering and Landscape Management, Vol XII, Suppl 2. Vilnius: Technika, 2004, p 67-72 (in Lithuanian).

10. Brannvall, E.; Kazlauskiene, A. Experimental research on sorption of $\mathrm{Pb}^{2+}, \mathrm{Zn}^{2+}, \mathrm{Cu}^{2+}, \mathrm{Mn}^{2+}, \mathrm{Ni}^{2+}, \mathrm{Na}^{+}, \mathrm{Ca}^{2+}$ and $\mathrm{Cl}^{-}$from solutions on clinoptilolite. In: Proceedings of 6th International Conference "Environmental Engineering", Vol 1, May 26-27. Vilnius: Technika, 2005, p 49-53.

11. Mažeikienè, A.; Rimeika, M.; Valentukevičienė, M.; Oškinis, V.; Paškauskaite, M.; Brannvall, E. Removal of petroleum products from water using natural sorbent zeolite. Journal of Environmental Engineering and Landscape Management, Vol XIII, No 4. Vilnius: Technika, 2005, p 187-191.

12. Färm, C. Metal sorption to natural filter substrate for storm water treatment-column studies. Science of the Total Environment, Vol 298, 2002, p 17-24.

13. Kesraoui-Ouki, S.; Cheeseman, C.R.; Perry, R. Natural zeolite utilization in pollution control: a review of applications to metals' effluents. Journal of Chemical Technology and Biotechnology, Vol 59, 1994, p 121-126.

14. Baltrènas, P.; Kliaugienè (Brannvall), E. Runoff-cleaning filter. Lithuanian Republic Patent No LT2003110. International classification C02F3/04. Date of announcement 25 Jul 2005.

15. LAND 9-2002. The requirements on treatment of polluted with oil products soil and groundwater and emission limits. Ministry of Environment of Lithuania. 2002, p 31 (in Lithuanian).

16. Mesyats, S.; Nesterova, M.; Gornickiy, A. Sorbent preparations for oil pollution cleanup in Northern Sea. Oceanology, Vol 24 (6), 1984, p 692-694.

17. Da Silva, J.; Melo, M.; de Silva, A.; Farias, R. Adsorption of crude oil on anhydrous and hydrophobized vermiculite. Journal of Colloid and Interface Science, Vol 260 (2). 2003, p 302-304.

18. Mysore, D.; Viraraghavan, T.; Jin, Y. Treatment of oily waters using vermiculite. Journal of Water Research, Vol 39, 2005, p 2643-2653.

\section{FILTRO SU NATŪRALIŲ SOBENTŲ İKROVA, SKIRTO SUNKIESIEMS METALAMS IR NAFTOS PRODUKTAMS IŠ LIETAUS NUOTEKŲ VALYTI, EKSPERIMENTINIAI TYRIMAI}

\section{P. Baltrènas, E. Brannvall}

$\mathrm{S}$ a $\mathrm{n} \mathrm{tr}$ a u k a

Atlikti eksperimentiniai sunkiujų metalų ir naftos produktų šalinimo iš tirpalų kaip sorbentus naudojant gamtinius ceolitą ir vermikulitą tyrimai. Šiam tikslui naudotas sukurto lietaus nuotekų valymo įrenginio maketas. Filtro įkrova $-25 \mathrm{~kg}$ gamtinio ceolito ir $2 \mathrm{~kg}$ vermikulito. Eksperimentiniam tirpalui paruošti sunaudota 201 distiliuoto vadens bei $1 \mathrm{~g} / 1$ sunkiujų metalų $\mathrm{Cu}, \mathrm{Pb}, \mathrm{Zn}, \mathrm{Ni}$ ir Mn bei po $200 \mathrm{ml}$ benzino ir dyzelino. Eksperimentinis tirpalas ipiltas į filtrą per piltuvèlį, tekejo pro ceolito ir vermikulito sluoksnius. Pirmasis mèginys paimtas iš čiaupo iškarto po tirpalo sąlyčio su filtro ikkrova - po 1 min., antrasis - po 5 min., o kiti - po 10, 20, 30,60,120, 240, 360 ir $720 \mathrm{~min}$. Filtrato mėginiai analizuoti TOG/TPH analizatoriumi, kuris nustato naftos 
produktų koncnetraciją tirpale. Didžiausias filtro efektyvumas - 99,7 \% pasiektas šalinant naftos produktus. Sunkieji metalai taip pat pašalinti efektyviai (pvz., $\mathrm{Pb}-98,6 \%$ ).

Prasminiai žodžiai: naftos produktai, sunkieji metalai, vandens teršimas, natūralusis sorbentas, ceolitas, vermikulitas.

Pranas BALTRÉNAS. Dr Habil, Prof and head of Dept of Environmental Protection, Vilnius Gediminas Technical University (VGTU).

Doctor Habil of Science (air pollution), Leningrad Civil Engineering Institute (Russia), 1989. Doctor of Science (air pollution), Ivanov Textile Institute (Russia), 1975. Employment: Professor (1990), Associate Professor (1985), senior lecturer (1975), Vilnius Civil Engineering Institute (VISI, now VGTU). Publications: co-author of 13 monographs, 24 study-guides, over 320 research papers and inventions. Honorary awards and membership: prize-winner of the Republic of Lithuania (1994), a corresponding Member of the Ukrainian Academy of Technological Cybernetics, a full Member of International Academy of Ecology and Life Protection. Probation in Germany and Finland. Research interests: air pollution, pollutant properties, pollution control equipment and methods.

Evelina BRANNVALL. Master, doctoral student (since 2002), Dept of Environmental Protection, Vilnius Gediminas Technical University (VGTU).

Employment: asisstant, Dept of Geotechnical Engineering, VGTU. Publications: co-author of 2 monographs, over 10 research papers and 1 invention. Research interests: technogenic geochemistry, soil remediation by using natural materials. 